\title{
Consumer Acceptance of Online Complaint Forms: An Integration of TPB, TAM and Values Perspective
}

\author{
Yang-Chieh Chin \\ Department of International Business, Asia University \\ 500, Lioufeng Rd., Wufeng, Taichung 41354, Taiwan
}

Tel: 886-42332-3456 ex. 20051 E-mail: chin@asia.edu.tw

Received: August 9, 2016 Accepted: August 26, 2016

doi:10.5296/ber.v6i2.10099 URL: http://dx.doi.org/10.5296/ber.v6i2.10099

\begin{abstract}
Although online complaint forms have long been used in the online environment, the problem of identifying the best of the prevalent theoretical models has been relatively ignored until a few studies recently attempted to examine this issue using the integrated model. This study explores the various advantages of online complaint forms in order to establish a positive factor named perceived value and the study further integrates the model of the theory of planned behavior (TPB) and the acceptance model (TAM) with the aim of explaining consumer acceptance of online complaint forms. Empirical data were obtained from a questionnaire survey fielded in Taiwan. A confirmatory factor analysis (CFA). using AMOS 19.0, was conducted to test the causal relationships. Notable among the findings was that an integrated model with perceived value is superior to the TPB and the TAM in terms of its ability to explain user acceptance of online complaint forms. Moreover, the predictors of the TPB and the TAM as well as perceived value have had different significant effects in predicting the intention of using an online complaint form. The findings also suggest that marketers need to formulate implementation strategies that enhance the likelihood of a user's seeing online complaint forms as a useful tool in lodging their complaints.
\end{abstract}

Keywords: Online Complaint Form, Perceived Value, The Theory of Planned Behavior, The Technology Acceptance Model

\section{Introduction}

Technological innovations and advances enhance the interactions between sellers and buyers (Meuter et al., 2000). Recent web technology advancements have also changed consumer evaluations and usage intentions. With the prevalence of the internet and the rapid progress of technology, companies have begun to use information technology to handle customer 
complaints in order to increase the speed of response. While consumers' complaints and complaint management in traditional stores has been thoroughly studied (East, 2000; Smith et al., 1999; Kim et al., 2003). the research on online complaints is far more rare.

It is plausible to assume that consumers' complaints are channel-specific (Zaugg, 2007) such that the channel used to receive the service may impact the choice of channel for expressing the complaint. For example, if consumers encounter an e-service failure, they may wish to express their concerns and dissatisfactions about their negative experiences over the Internet. The service provider should seek an effective online communication tool for handling customer complaints. Therefore, the goal of online complaint forms is to resolve online complaints involving buyers and sellers in a fair and timely way.

Online consumers are the primary users of online complaint forms, and their acceptance of that process is often crucial to the success of the complaint technology. Several studies investigate the effects of beliefs and attitude on IT usage intentions and behaviors based on the theory of planned behavior (TPB) and the technology acceptance model (TAM) (Ajzen and Fishbein, 1977; Davis et al., 1989; Taylor and Todd, 1995). However, although the concept of value is old and endemic to consumer behavior, many authors have recognized a lack of interest in understanding and measuring perceived value (e.g., Holbrook, 1999). and few have discussed perceived value in consumer complaint behavior using the TPB and the TAM. This study explores the advantages of online complaints to achieve insight from a standpoint of perceived value (consisting of performance/quality value, service value and convenience value) so as to provide a more comprehensive model of the consumer acceptance of online complaint forms. Therefore, the purposes of this work are as follows:

1. To clarify which factors are more influential in affecting the decision to use an online complaint form.

2. To evaluate whether the integration of the TPB with the TAM provide a solid theoretical basis for examining the consumer acceptance of online complaint forms.

3. Beyond studying the attributes of the TPB and the TAM, this study attempts to investigate whether perceived value significantly impacts customers' behavioral intention to use an online complaint form.

\section{Literature review}

\subsection{Online Complaints}

Consumers' complaints are generally a set of multiple responses arising out of purchase dissatisfactions (Singh, 1988, 1990). When complainers express negative feelings of displeasure or dissatisfaction after meeting service failures, inadequate handling of those complaints increases frustration and dissatisfaction, reinforces negative consumer reactions, and harms a seller's reputation (Hoffman and Chung, 1999; Mattila, 2001). Thus, the complaint mechanism in the online environment should be considered carefully because, if they don't like it, online consumers may choose to do nothing about their dissatisfaction and instead take the easy option of switching their purchasing actions to another website. 
Moreover, online customer complaints made in a web-based environment are different in nature from more traditional customer complaints (Cho et al., 2003). When service failures occur, most customers complain by telephone, which is generally the company's preferred channel. However, because of its low transmission costs, the company may also choose to promote the e-channel (email and web form) over letters and faxes (Zaugg, 2007). Therefore, complaint management using online complaint forms or systems becomes an important element in the complaint-handling process.

\subsection{The Theory of Planned Behavior (TPB)}

The Theory of Planned Behavior (TPB) emphasizes that an individual's behavior can be explained by his or her behavioral intentions, which are influenced by attitude, the subjective norm, and perceived behavioral control. Attitude toward a behavior is defined as the degree to which a person has a favourable or unfavourable evaluation or appraisal of the behavior in question. The TPB predicts that the more favourably an individual evaluates a particular behavior, the more likely he or she will intend to perform that behavior (Ajzen, 1987). The subjective norm as it relates to a behavior is the person's perception of the social pressure to perform or not to perform the behavior in question. Venkatesh and Davis (2000) found strong support for a direct link between the subjective norm and intention. Perceived behavioral control refers to the perceived ease or difficulty of performing the behavior and the amount of control one has over the achievement of personal goals. This variable is expected to make consumers more capable of controlling the environment for online complaints, which would prompt them to be more willing to accept the technology of an online complaint form (Lee $e t$ $a l .$, 2006). Perceived behavioral control is also a useful measure in situations in which people may lack complete volitional control over the behavior in question (Ajzen, 1985, 1988, 1991). Therefore, in an online complaint context, a complainer's intention to use an online complaint form may be determined by his or her attitude toward using an online complaint form, his or her subjective norms, and his or her perceived behavioral control.

\subsection{The Technology Acceptance Model (TAM)}

The Technology Acceptance Model (TAM). an adaptation of the Theory of Reasoned Action (TRA). is a very powerful and parsimonious model for explaining and predicting much of the variance in consumers' acceptance of new information technology. The TAM predicts that user acceptance of technology is determined by three factors: perceived usefulness, perceived ease of use, and behavioral intentions. Davis et al. (1989) pointed that both perceived usefulness and perceived ease of use directly mediate the behavioral intention (with perceived ease of use also having a direct positive effect on perceived usefulness). Perceived usefulness is the prospective user's subjective sense that using a specific application system will increase his or her job performance within a specified context. Perceived ease of use refers to the degree to which the prospective user expects the target system to be free of effort. Indeed, online complainers need an understandable, consistent, and intuitive platform accompanied by a site function that makes it easy to express what he/she wants. Perceived usefulness and perceived ease of use are statistically distinct dimensions in explaining technology adoption (Hauster and Shugan, 1989) which will influence customers' acceptance of an online 
complaint form.

However, the integrated model of the TPB and the TAM has seldom been used in a complaint context.

\subsection{Perceived Values}

Perceived value is based on the sum of perceptions of various product and service benefits and associated tradeoffs. It is a consumer's overall assessment of the utility of a product or service based on his or her perceptions of what is received versus what is offered (Zeithaml, 1988). As such, overall perceived value was treated as a molar perception (Bagozzi, 1985) formed by three affective responses to an online complaint form. We assumed that the three components would exert varying effects on the overall perceived value.

First, the performance/quality dimension (performance/quality value) reflects the consistency and the network quality of the design. The importance of the concept of perceived performance/quality has been recognized (Kettinger and Lee, 2005) and its direct impact on attitude and behavioral outcomes has been validated (Wixom and Todd, 2005). Nevertheless, its effect on an overall value has not been explored. The marketing literature has reported on studies that have shown that higher performance/quality evaluations lead to higher overall value (e.g., Baker et al., 2002). Accordingly, we anticipate that performance/quality value will lead to positive attitude toward using online complaints and produce the intention to lodge complaints in an online complaint form.

Second, service value was defined as a relative judgment of gets and gives, and represents the utility derived from a service exchange (Ostrom and Iacobucci, 1995). Online complaint forms have recently come to be considered as one of the most effective complaint handling systems because it possesses many advantages which offline communication channels cannot offer. Thus, online service providers aim to utilize these service advantages to increase the online complaint form adoption rate. Based to a certain degree on reasons offered by Ulaga and Eggert (2005). who indicated that service value refers to obtaining immediate and tangible benefits: customers would then willingly use online complaint forms to express their complaints. That is, customers can benefit from a wider range of fast transaction speed and increased information transparency from online complaint forms. In addition, online complaint forms allow a customer to submit complaints from anywhere in the world and enjoy 24-hour service. Online complaint forms offer customers more service responses, such as an apology email and a requested remedy. The service value will be considered in the preliminary model of the acceptance of online complaint forms.

The third factor of value, effort-saving capability, is defined as a class of convenience. Indeed, time-savings were seen as a key element of convenience value (Yale and Venkatesh, 1986). Recently, convenience was found to be a dominating value dimension for driving information technology (Pihlström and Brush, 2008). Also, convenience value will lead to a user's positive attitude and the intention of using online complaint forms. 


\section{1) Macrothink}

\section{Hypotheses development}

\subsection{Hypotheses about the TPB and the TAM}

Although the TPB and the TAM have been found to provide consistently superior explanations or predictions of consumer intention (Taylor and Todd, 1995; Venkatesh et al., 2003). factors influencing consumers' adoption of technology can vary depending on the technology, target consumers, and context. Chau and $\mathrm{Hu}$ (2002) state that "theory testing follows replication logic and hence makes theory comparison an attractive approach, i.e., generating support for a theory (or some distinct theories) and, at the same time, singling out the potential limitation of others" (p. 298). Dishaw and Strong (1999) also indicate that an integrated model may provide more explanatory power than either model alone. Thus, we propose a research framework integrating elements derived from both the TPB and the TAM since they are leading theoretical models and have accumulated fairly strong empirical support from studies involving various end-users and business managers.

In the context of complaints, the TPB suggests that a complainer is more willing to complain if he or she has a positive attitude toward using an online complaint form, depends on other important people's opinions about the online complaints, and has the requisite resources, skills, and opportunities to do so. In addition, by using the TAM as a basic structure in this research context, we can determine whether the favourable system attributes of the online complaint form-perceived usefulness and perceived ease of use-will positively influence complainers' attitude toward an online complaint form. Moreover, perceived usefulness has a direct effect on the intention to use an online complaint form, and perceived ease of use has a direct effect on perceived usefulness of an online complaint form. Accordingly, the hypotheses are presented in Fig. 1.

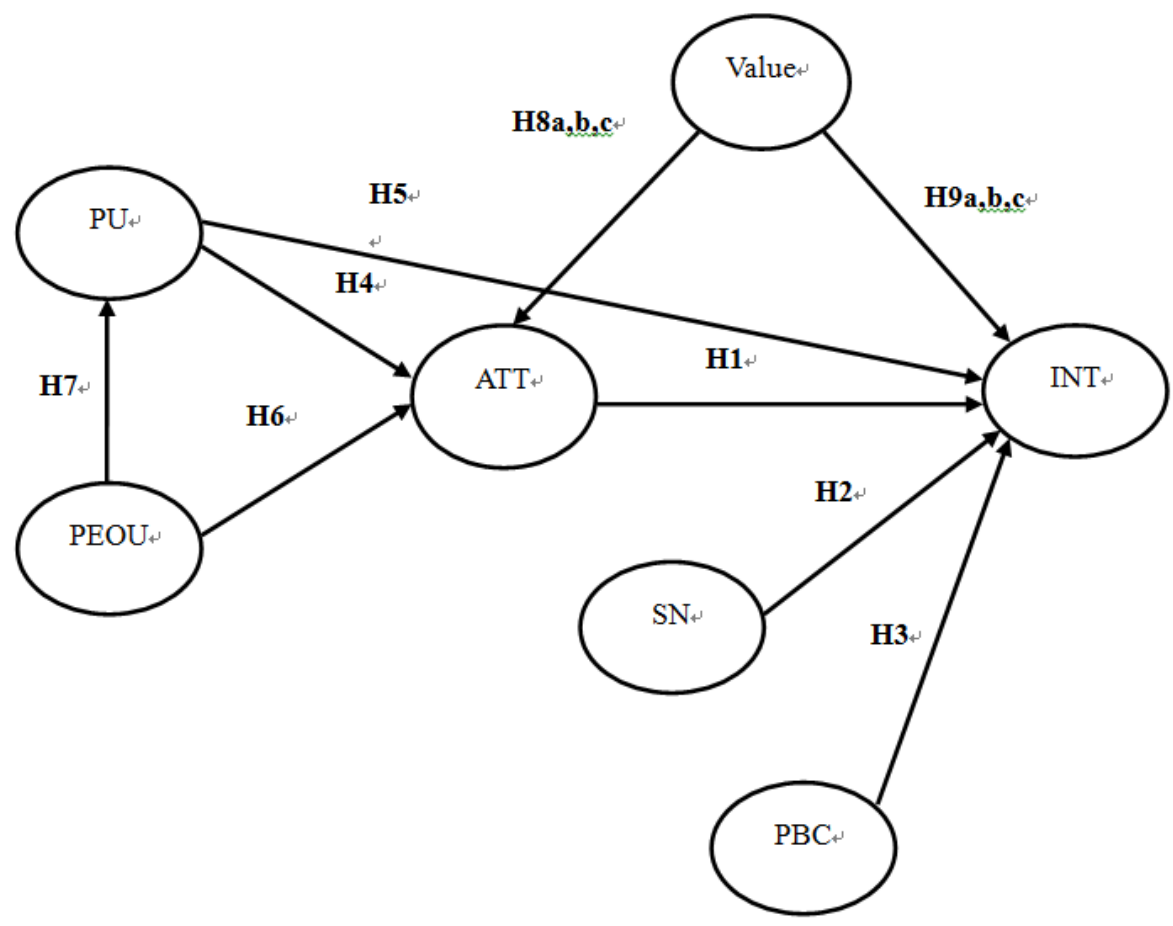

Figure 1. The integrated model and research hypotheses. 


\section{Ml Macrothink}

Business and Economic Research

ISSN 2162-4860

2016, Vol. 6, No. 2

H1. The attitude toward using an online complaint form will have a positive impact on the intention to use such an online form.

H2. The subjective norm will have a positive impact on the intention to use an online complaint form.

H3. The perceived behavioral control will have a positive impact on the intention to use an online complaint form.

H4. The perceived usefulness will have a positive impact on the attitude toward using an online complaint form.

H5. The perceived usefulness of an online complaint form will have a positive impact on the intention to use an online complaint form.

H6. The perceived ease of use of an online complaint form will have a positive impact on the attitude toward using an online complaint form.

H7. The perceived ease of use of an online complaint form will have a positive impact on the perceived usefulness of an online complaint form.

\subsection{Hypotheses about the TPB, TAM and Values}

Recent evidence shows that perceived value significantly affects information technology adoption (Venkatesh, 2006). Along the same lines, Kim (2011) pointed that perceived value has a positive influence on the IT/IS adoption. For instance, online complaint forms offer fast transaction speed and better information transparency as well as allowing customers to log in their problems and observe what solved it so the customer can detect a response pattern and enjoy 24-hour services, which will enhance customer's perception of values. Therefore, it is reasonable to infer that the perceived value positively influences consumer attitude and intention to use an online complaint form, and we hypothesize that:

H8a. The performance/quality dimension of perceived value of online complaint forms is positively associated with the attitude toward using online complaint forms.

H8b. The service dimension of perceived value of online complaint forms is positively associated with the attitude toward using online complaint forms.

H8c. The convenient dimension of perceived value of online complaint forms is positively associated with the attitude toward using online complaint forms.

H9a. The performance/quality dimension of perceived value of online complaint forms is positively associated with the overall perceived value of online complaint forms.

H9b. The service dimension of perceived value of online complaint forms is positively associated with the overall perceived value of online complaint forms.

H9c. The convenient dimension of perceived value of online complaint forms is positively associated with the overall perceived value of online complaint forms. 


\section{Research Methodology}

\subsection{Sample and Procedure}

In order to target online consumers, an e-mail survey was employed. A total of 320 questionnaires were randomly distributed by e-mail (where available) to consumers who had shopped in an online store before. The e-mail also linked to a web site where participants could fill out an online questionnaire. Participants were asked to read scenario descriptions about a hypothetical online service failure problem, as well as responding to the questionnaire about using an online complaint form. Of respondents, 58 questionnaires were excluded from the sample because of incomplete responses or lack of online shopping experiences in the past six months, so 262 samples remained for the final analysis, which yields a 82 percent usable response rate. The respondents were comprised of $47.1 \%$ males and $52.9 \%$ females, and the age range of the participants was 19-40. Sixty-eight percent of the participants had a bachelor's degree and 32\% had earned a master's degree or higher, indicating that the respondents to this research were well educated. In addition, most of the participants had more than 4 years of computer experience.

\subsection{Measures}

The measures were modelled after Ajzen and Fishbein (1980) and Davis et al. (1989). All variables were measured using a five-point Likert-type scale, from $1=$ completely disagree to 5 = completely agree.

Intention to use an online complaint form (INT). The dependent variable was the INT, the intention of the dissatisfied consumer to make a complaint to the firm (Kim et al., 2003). Respondents' intention to complain online was measured using three items adapted from Singh (1989). Responses to the three items were averaged, and this average represented the participant's INT score.

Attitude (ATT). The ATT was tested with four items adapted from Bhattacherjee (2000).

Subjective norm (SN). The SN scale, developed by Taylor and Todd (1995) and Bhattacherjee (2000). consisted of three items.

Perceived behavioral control (PBC). The PBC was adapted from the measurement defined by Taylor and Todd (1995) and Bhattacherjee (2000) and consisted of three items.

Perceived usefulness (PU). Based on the instrument of Venkatesh and Davis (2000) and Davis (1989). four items measured the PU.

Perceived ease of use (PEOU). The PEOU was adapted from the study of Venkatesh and Davis (2000) and Davis (1989) and consisted of four items.

Perceived value (PV). The PV was included three dimensions: performance/quality value, service value and convenience value, which were adapted from the measurements defined by Turel et al. (2002). Zeithaml (1988) and Anderson and Srinivasan (2003). 


\section{Results}

\subsection{Measurement Model}

A confirmatory factor analysis (CFA). using AMOS 19.0, was conducted to test the measurement model. Six common model-fit measures were used to assess the model's overall goodness-of-fit: the ratio of $\chi^{2}$ to degrees-of-freedom ( $d f$ ); goodness-of-fit index (GFI); normalized fit index (NFI); comparative fit index (CFI); root mean residual (RMR) and root mean square error of approximation (RMSEA). As shown in Table 1, all the model-fit indices exceeded their respective common acceptance levels, as suggested by previous research, demonstrating that the measurement model exhibited a fairly good fit with the data collected. Thus, we proceeded to evaluate the psychometric properties of the measurement model in terms of reliability, convergent validity and discriminant validity.

Table 1. Fit indices and explanatory power for three models

\begin{tabular}{|c|c|c|c|c|}
\hline & Recommended value & TPB & TAM & Integrated with values \\
\hline \multicolumn{5}{|c|}{ Model goodness-of-fit indexes } \\
\hline$\chi^{2} / d f$ & $\leq 3$ & 1.80 & 1.71 & 1.53 \\
\hline GFI & $\geq 0.90$ & 0.92 & 0.94 & 0.94 \\
\hline NFI & $\geq 0.90$ & 0.90 & 0.91 & 0.93 \\
\hline CFI & $\geq 0.95$ & 0.93 & 0.95 & 0.95 \\
\hline RMR & $\leq 0.05$ & 0.02 & 0.02 & 0.01 \\
\hline RMSEA & $\leq 0.08$ & 0.05 & 0.04 & 0.03 \\
\hline \multicolumn{5}{|c|}{ Exploratory power } \\
\hline$R_{B I}^{2}$ & & 0.51 & 0.70 & 0.76 \\
\hline$R^{2}{ }_{A T T}$ & & - & 0.63 & 0.61 \\
\hline$R_{P U}^{2}$ & & - & 0.41 & 0.44 \\
\hline
\end{tabular}

Reliability and convergent validity of the factors were estimated by composite reliability and average variance extracted. Composite reliability for all the factors in our measurement model was above 0.70 , and the average extracted variances were all above the recommended 0.50 level (Hair et al., 1992). which meant that more than half of the variances observed in the items were accounted for by their hypothesized factors. All of the factor loadings of the items in the research model were greater than 0.50 , with most above 0.80 . All factors in the measurement model had adequate reliability and convergent validity. To examine discriminant validity, this study compared the shared variances between factors with the average variance extracted from the individual factors (Fornell and Larcker, 1981). The test of discriminant validity revealed good discriminant validity. 


\subsection{Structural Model}

Comparison of all fit indices with their corresponding recommended values provided evidence of a good model fit (Table 1). For the integrated TPB/TAM model, the results of the CFA indicated that the structural model provided a very good fit to the data: $\chi^{2} / d f=1.53$, $p<0.001, \mathrm{GFI}=0.94, \mathrm{NFI}=0.93, \mathrm{CFI}=0.95, \mathrm{RMR}=0.01$, and $\mathrm{RMSEA}=0.03$. All of the model-fit indices exceeded their common respective acceptance levels (Table II). We also examined the path coefficients of the structural model. Properties of the causal paths, including standardized path coefficients and an explanation of variance for each equation in the hypothesized model, are presented in Table 2. As expected, hypotheses H1, H2, H3, H5 and H9a, b, c were supported in that ATT, SN, PBC, PU and PV all had a significant effect on the INT. In the TAM and an/the integrated model, PEOU and PV were significant on ATT, while PEOU was also significant on PU. So, H4, H6 and H8a, b, c were supported. We conclude that the TPB model should be extended with PEOU, PU and PV when explaining the adoption of online complaint forms.

Table 2. Significance of individual paths in three models

\begin{tabular}{|c|c|c|c|c|}
\hline Path & & th coeffici & & Hypothesis \\
\hline & TPB & TAM & Integrated & \\
\hline $\mathrm{ATT} \rightarrow \mathrm{INT}$ & $0.45 * * *$ & - & $0.41 * * *$ & H1(Supported) \\
\hline $\mathrm{SN} \rightarrow \mathrm{INT}$ & $0.11 * * *$ & - & $0.10 * * *$ & H2(Supported) \\
\hline $\mathrm{PBC} \rightarrow \mathrm{INT}$ & $0.56 * * *$ & - & $0.48 * * *$ & H3(Supported) \\
\hline $\mathrm{PU} \rightarrow \mathrm{ATT}$ & - & $0.35 * * *$ & $0.38 * * *$ & H4(Supported) \\
\hline $\mathrm{PU} \rightarrow \mathrm{INT}$ & - & $0.28 * * *$ & $0.24 * * *$ & H5(Supported) \\
\hline $\mathrm{PEOU} \rightarrow \mathrm{ATT}$ & - & $0.27 * * *$ & $0.29 * * *$ & H6(Supported) \\
\hline $\mathrm{PEOU} \rightarrow \mathrm{PU}$ & - & $0.58 * * *$ & $0.50 * * *$ & H7(Supported) \\
\hline $\mathrm{PV}-\mathrm{PQV} \rightarrow \mathrm{ATT}$ & - & - & $0.42 * * *$ & H8a(Supported) \\
\hline $\mathrm{PV}-\mathrm{SV} \rightarrow \mathrm{ATT}$ & - & - & $0.34 * * *$ & H8b(Supported) \\
\hline $\mathrm{PV}-\mathrm{CV} \rightarrow \mathrm{ATT}$ & - & - & $0.40 * * *$ & H8c(Supported) \\
\hline $\mathrm{PV}-\mathrm{PQV} \rightarrow \mathrm{INT}$ & - & - & $0.31 * * *$ & H9a(Supported) \\
\hline $\mathrm{PV}-\mathrm{SV} \rightarrow \mathrm{INT}$ & - & - & $0.24 * * *$ & H9b(Supported) \\
\hline $\mathrm{PV}-\mathrm{CV} \rightarrow \mathrm{INT}$ & - & - & $0.36 * * *$ & H9c(Supported) \\
\hline
\end{tabular}

Note: $p^{*}<0.05 ; p^{* *}<0.01 ; p^{* * *}<0.001$.

\section{Discussion and Implications}

Given the high competitiveness of the online market, online companies attach great importance to retaining customers. The majority of these companies only offer phone numbers for their customers to communicate with them. Recently, technological advances have made it possible for complaints to be submitted through the Internet. This study combines the TPB/TAM and the construct of perceived value to predict intent to complain 
online.

Empirical findings found that the TPB (Fishbein and Ajzen, 1975). the TAM (Davis et al., 1989). and an integrated model with perceived value confirmed the usage of online complaint forms. In particular, an integrated model with perceived value showed high explanatory power $(76 \%)$ of the intention. That is, the result demonstrated that the integration of the TPB/TAM with perceived value is a powerful model when consumers have incomplete volitional control. As expected, the predictors in the model fit well in explaining the acceptance of online complaint forms. In an e-complaint management context, a thorough and speedy follow-up response that resolves the customer's problem is a crucial step in the successful implementation of online complaint forms (Mattila and Mount, 2003).

The results showed that attitude toward using an online complaint form plays the most important role in determining the intention to use such an online form. The findings also suggested that perceived ease of use, perceived usefulness and perceived value impact the attitude toward using an online complaint form positively. In order to enhance that attitude, marketers should emphasize that information privacy is respected and security is considered when consumers lodge their complaints and that, when customers use the Web to lodge complaints, they will receive a quick reply. Moreover, an easy and beneficial modification can enhance the usage of online complaint forms and improve attitude; and the more positive the attitude, the greater the intention to use an online complaint form.

Consistent with previous research (Kang et al., 2006; Lee et al., 2006). the findings showed that perceived behavioral control of online complaint form usage is a significant antecedent to the intention of using such an online form. Thus, efforts to give consumers a positive perception about their behavioral control are critical in order for marketers to increase the effectiveness of online complaint forms. Since consumers' usage of online complaint forms requires skill, opportunity, and resources, marketers may want to educate online consumers as to how to lodge complaints online, thereby strengthening consumers' perceptions of control by enhancing their Internet skill levels.

At the same time, perceived value is another major predictor of the intention in using an online complaint form. Indeed, our results indicate that perceived value provide insights as to why the value concept is so crucial for marketing researchers. Performance/quality value, service value and convenience value have significant explanatory power in predicting user's attitude and the intention to use online complaint forms. Perceived value can predict the intention to adopt an online complaint form well effectively This result is congruent with the findings of Tanford et al., (2011). who indicate that perceived value has a positive influence on website adoption. If consumers encounter a service failure, they can use an online complaint form a lot faster than they could with a physical communications, such as telephone communication with a salesperson. In a multichannel context, consumers may compare the efficiency of communication channels and tools. That is, consumer' perceived value will directly influence their intentions to adopt an online complaint form. The more dimensions of value of using an online complaint form can be perceived, the more engaged users are. Marketers need to formulate implementation strategies that would enhance the 
likelihood of a user's seeing online complaint forms as a useful tool in lodging their complaints. Moreover, convenience value will have a more positive influence on the attitude and the adoption intention than those of performance/quality value and service value. This result was consistent with Pura (2005). who indicated that service providers have to reinforce the convenience value such as speed of performing a task effectively and conveniently to get competitive advantage, while continuing to improve performance/quality value and service value.

\subsection{Limitations and Future Research}

While this research adds to the current literature on online consumers' intention to choose a channel to submit a complaint, the results should be treated cautiously because of a number of limitations. First, this study does not incorporate actual customer behavior in the proposed model, although this is not a serious limitation because there is substantial empirical support for the causal link between intention and behavior (Taylor and Todd, 1995; Venkatesh and Davis, 2000; Venkatesh et al., 2003). Second, the lack of situational factors may have an effect on the model. Further research should also investigate the possible influence of situational factors such as demographic characteristics of users (Meuter et al., 2003). In other words, the customers' acceptance of online complaint forms might be indirectly affected by customer characteristics. This needs further investigation and validation. Third, the integrated model is cross-sectional; that is, it measures perceptions and intentions at a single point in time. Future research could employ a longitudinal study to evaluate this aspect.

\section{References}

Ajzen, I. (1987). Attitudes, traits, and actions: dispositional prediction of behavior in personality and social psychology, Advances in Experimental Social Psychology, 20, 1-63. http://dx.doi.org/10.1016/S0065-2601(08)60411-6

Ajzen, I. (1985). From intention to actions: a theory of planned behavior, in Kuhl, J. and Bechmann, J. (eds.). Action control: From cognition to behavior (pp. 11-39). Springer, NY. http://dx.doi.org/10.1007/978-3-642-69746-3_2

Ajzen, I. (1988). Attitudes, Personality and Behavior, The Dorsey Press, Chicago.

Ajzen, I. (1991). The theory of planned behavior, Organizational Behavior and Human Decision Processes, 50(2), 179-211. http://dx.doi.org/10.1016/0749-5978(91)90020-T

Ajzen, I., \& Fishbein, M. (1977). Attitude-behavior relations: a theoretical analysis review of empirical research, Psychological Bulletin, 84(3), 888-914. http://dx.doi.org/10.1037/0033-2909.84.5.888

Ajzen, I., \& Fishbein, M. (1980). Understanding Attitudes and Predicting Social Behavior, Englewood Cliffs, Prentice-Hall, NJ.

Bagozzi, R. P. (1985). Expectancy-value attitude models: an analysis of critical theoretical issues, International Journal of Research Marketing, 2(1), 43-60. http://dx.doi.org/10.1016/0167-8116(85)90021-7 


\section{$\triangle 1$ Macrothink}

Business and Economic Research ISSN 2162-4860 2016, Vol. 6, No. 2

Baker, J., Parasuraman, A., Grewal, D., \& Voss, G. B. (2002). The influence of multiple store environment cues on perceived merchandise value and patronage intentions, Journal of Marketing, 66(2), 120-41. http://dx.doi.org/10.1509/jmkg.66.2.120.18470

Bhattacherjee, A. (2000). Aceptance of e-commerce services: te case of electronic brokerages, IEEE Transactions on System, Man, and Cybernetics-Part A: Systems and Human, 30(2), 411-20. http://dx.doi.org/10.1109/3468.852435

Chau, P. Y. K., \& Hu, P. J. H. (2002). Investigating healthcare professionals' decisions to accept telemedicine technology: an empirical test of competing theories, Information \& Management, 39(4), 297-311. http://dx.doi.org/10.1016/S0378-7206(01)00098-2

Cho, Y., Im, I., \& Hiltz, R. (2003). The impact of e-services failures and customer complaints on electronic commerce customer relationship management, Journal of Consumer Satisfaction Dissatisfaction and Complaining Behavior, 16, 106-18.

Davis, F. D. (1989). Perceived usefulness, perceived ease of use, and user acceptance of information technology, MIS Quarterly, 13(3), 319-40. http://dx.doi.org/10.2307/249008

Davis, F. D., Bagozzi, R. P., \& Warshaw, P. R. (1989). User acceptance of computer technology: a comparison of two theoretical models, Management Science, 35(8), 982-1003. http://dx.doi.org/10.1287/mnsc.35.8.982

Dishaw, M. T., \& Strong, D. M. (1999). Extending the technology acceptance model with task-technology fit constructs, Information \& Management, 36(1), 9-21. http://dx.doi.org/10.1016/S0378-7206(98)00101-3

East, R. (2000). Complaining as planned behavior, Psychology \& Marketing, 17(12), 1077-95. http://dx.doi.org/10.1002/1520-6793(200012)17:12<1077::AID-MAR4>3.0.CO;2-W

Fishbein, M., \& Ajzen, I. (1975). Beliefs, Attitudes, Intention, and Behavior: An Introduction of Theory and Research, Addison Wesley Publishing, Reading, MA.

Fornell, C., \& Larcker, D. F. (1981). Evaluating structural equation models with unobservable variables and measurement error, Journal of Marketing Research, 18(1), 39-50. http://dx.doi.org/10.2307/3151312

Hair, J. F., Anderson, R. E., Tatham, R. L., \& Black, W. C. (1992). Multivariate Data Analysis with Readings (3rd ed.). Macmillan Publishing, NY.

Hauster, J. R., \& Shugan, S. M. (1980). Intensity measures of consumer preference, Operation Research, 28(2), 278-320. http://dx.doi.org/10.1287/opre.28.2.278

Holbrook, M. B. (1999). Consumer Value, a Framework for Analysis and Research, Routledge, London. http://dx.doi.org/10.4324/9780203010679

Hoffman, K. D., \& Chung, G. B. (1999). Hospitality recovery strategies: customer preference versus firm use, Journal of Hospitality \& Tourism Research, 23(1), 71-84. http://dx.doi.org/10.1177/109634809902300106 
Kang, H., Hahn, M., Fortin, D. R., Hyun, Y. J., \& Eom, Y. (2006). Effects of perceived behavioral control on the consumer usage intention of e-coupons, Psychology \& Marketing, 23(10), 841-64. http://dx.doi.org/10.1002/mar.20136

Kettinger, W. J., \& Lee, C. C. (2005). Zones of tolerance: alternative scales for measuring information systems service quality, MIS Quarterly, 29(4), 607-23.

Kim, G. J. (2011). Consumer adoption in digital multimedia broadcasting: examining socio-cultural and economic determinants, International Journal of Information Technology and Management, 10(1), 80-93. http://dx.doi.org/10.1504/IJITM.2011.037764

Kim, C., Kim, S., Im, S., \& Shin, C. (2003). The effect of attitude and perception on consumer complaint intentions, Journal of Consumer Marketing, 20(4), 352-71. http://dx.doi.org/10.1108/07363760310483702

Lee, M. C. (2008). Predicting behavioral intention to use online banking, in Proceedings of the 19th International Conference on Information Management, Taiwan.

Lee, S. M., Kim, I., Rhee, S., \& Trimi, S. (2006). The role of exogenous factors in technology acceptance: the case of object-oriented technology, Information \& Management, 43(4), 469-80. http://dx.doi.org/10.1016/j.im.2005.11.004

Mattila, S. A. (2001). The effectiveness of service recovery in a multiindustry setting, Journal of Services Marketing, 15(7), 583-96. http://dx.doi.org/10.1108/08876040110407509

Mattila, S.A. and Mount, D.J. (2003). The impact of selected customer characteristics and response time on e-complaint satisfaction and return intent, International Journal of Hospitality Management, Vol. $22 \quad$ No. $\quad 2, \quad$ pp. 135-45. http://dx.doi.org/10.1016/S0278-4319(03)00014-8

Meuter, M. L., Ostrom, A. L., Roundtree, R. I., \& Bitner, M. J. (2000). Self-service technologies: understanding customer satisfaction with technology-based service encounters, Journal of Marketing, 64(3), 50-64. http://dx.doi.org/10.1509/jmkg.64.3.50.18024

Meuter, M. L, Ostrom, A. L., Bitner, M. J., \& Roundtree, R. (2003). The influence of technology anxiety on consumer use and experiences with self-service technologies, Journal of Business Research, 56(11), 899-907. http://dx.doi.org/10.1016/S0148-2963(01)00276-4

Ostrom, A., \& Iacobucci, D. (1995). Consumer trade-offs and the evaluation of services, Journal of Marketing, 59(1), 17-28. http://dx.doi.org/10.2307/1252011

Pura, M. (2005). Linking perceived value and loyalty in location-based mobile services, Managing Service Quality, 15(6), 509-38. http://dx.doi.org/10.1108/09604520510634005

Singh, J. (1988). Consumer complaint intentions and behavior: definitional and taxonomical issues, Journal of Marketing, 52(1), 93-107. http://dx.doi.org/10.2307/1251688

Singh, J. (1989). Determinants of consumers' decisions to seek third party redress: an empirical study of dissatisfied patients, Journal of Consumer Affairs, 23(2), 329-63. http://dx.doi.org/10.1111/j.1745-6606.1989.tb00251.x 
Singh, J. (1990). A typology of consumer dissatisfaction response styles, Journal of Retailing, 66(1), 57-99.

Smith, A. K., Bolton, R. N., \& Wagner, J. (1999). A model of customer satisfaction with service encounters involving failure and recovery, Journal of Marketing Research, 36(3), 356-72. http://dx.doi.org/10.2307/3152082

Tanford, S., Baloglu, S., \& Erdem, M. (2011). Travel packaging on the Internet: the impact of pricing information and perceived value on consumer choice, Journal of Travel Research, forthcoming.

Taylor, S., \& Todd P. A. (1995). Understanding information technology usage: a test of competing models, Information System Research, 6(2), 144-76. http://dx.doi.org/10.1287/isre.6.2.144

Turel, O., Serenko, A., \& Bontis, N. (2010). User acceptance of hedonic digital artifacts: a theory of consumption values perspective, Information \& Management, 47(1), 53-9. http://dx.doi.org/10.1016/j.im.2009.10.002

Ulaga, W., \& Eggert, A. (2005). Relationship value in business markets: the construct and its dimensions, Journal of Business-to-Business Marketing, 12(1), 73-99. http://dx.doi.org/10.1300/J033v12n01_04

Venkatesh, V., \& Davis, F. D. (2000). A theoretical extension of the technology acceptance model: four longitudinal studies, Management Science, 46(2), 186-204. http://dx.doi.org/10.1287/mnsc.46.2.186.11926

Venkatesh, V. (2006). Where to from Here? Thoughts on future directions for research on individual-level technology adoption with a focus on decision making, Decision Sciences, 37(4), 497-518. http://dx.doi.org/10.1111/j.1540-5414.2006.00136.x

Venkatesh, V., Morris, M. G., Davis, G. B., \& Davis, F. D. (2003). User acceptance of information technology: toward a unified view, MIS Quarterly, 27(3), 425-78.

Wixom, B. H., \& Todd, P. A. (2005). A theoretical integration of user satisfaction and technology acceptance, Information Systems Research, 16(1), 85-102. http://dx.doi.org/10.1287/isre.1050.0042

Yale, L., \& Venkatesh, A. (1986). Toward the construct of convenience in consumer research, Advances in Consumer Research, 13(1), 403-8.

Zaugg, A. D. (2007). Online complaint management @Swisscom: a case study, in Arbeitsbericht Nr. 193 des Instituts für Wirtschaftsinformatik, Abteilung Information Management, Universität Bern, 1-21.

Zeithaml, V. A. (1988). Consumer perceptions of price, quality and value: a means-end model and synthesis of evidence, Journal of Marketing, 52(3), 2-22. http://dx.doi.org/10.2307/1251446 


\section{Copyright Disclaimer}

Copyright for this article is retained by the author(s), with first publication rights granted to the journal.

This is an open-access article distributed under the terms and conditions of the Creative Commons Attribution license (http://creativecommons.org/licenses/by/3.0/). 